\title{
Reviewer Acknowledgements for Global Journal of Health Science, Vol. 11, No. 13
}

Global Journal of Health Science wishes to acknowledge the following individuals for their assistance with peer review of manuscripts for this issue. Their help and contributions in maintaining the quality of the journal are greatly appreciated.

Global Journal of Health Science is recruiting reviewers for the journal. If you are interested in becoming a reviewer, we welcome you to join us. Please find the application form and details at http://recruitment.ccsenet.org and e-mail the completed application form to gjhs@ccsenet.org.

\section{Reviewers for Volume 11, Number 13}

Althea Jane Gamble Blakey, University of Otago, New Zealand

António Calha, Polytechnic Institute of Portalegre, Portugal

Arpad Kovacs, University of Kaposvar, University of Pecs, Hungary

Celia Moffat Joel Matyanga, Harare Institute of Technology, Zimbabwe

David John Lindsay, James Cook University, Australia

David Otieno Odongo, Masinde Muliro University of Science and Technology, Kenya

David Richard Walwyn, University of Pretoria, South Africa

Diadie Maiga, Management Sciences for Health in Arlington, United States of America

Evanthia Sakellari, Technological Educational Institute of Athens, Greece

Fengsong Gao, The University of Queensland, Australia

Gabriel Gulis, University of Southern Denmark, Denmark

Gunta Beta, Rīgas Stradiņa universitāte, Latvija

Hadii M Mamudu, East Tennessee State University, United States of America

Hülya YARDIMCI, Ankara University, Turkey

Jan Chrastina, Palacký University, Czech Republic

José Joaquín Mira, Universidad Miguel Hernández, Spain

Kartheek R Balapala, University Tunku Abdul Rahman, Malaysia

Loray Daws, British Columbia Masterson Institute, Canada

Meng Zhao, Texas A\&M University at Corpus Christi, United States of America

Polly Yeung, Massey University, New Zealand

Myo Nyein Aung, Boromrajonani College of Nursing, Thailand

Pedram Iranmanesh, Dentist, Independent Researcher,Iran

Roger Ho Chun Man, National University of Singapore, Singapore

Roslyn Kane, University of Lincoln, United Kingdom

Santha James, Australian Catholic University, Australia

Sara Melo, Queen's University Belfast, United Kingdom

Tan Ching Siang, Universiti Sciences Malaysia, Malaysia

Thammanard Charernboon, Thammasat University, Thailand

Zohreh Vanaki, Tarbiat Modares University, Iran 